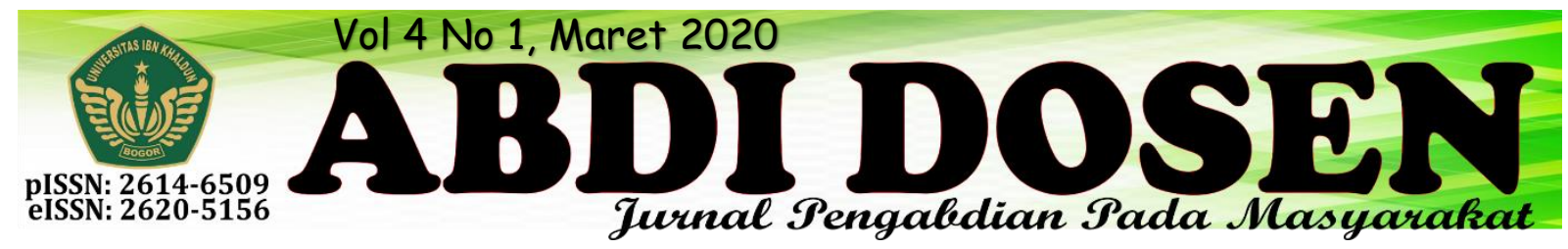

\title{
PENGOLAHAN SAMPAH MANDIRI DENGAN INSENERASI SEDERHANA MINIM ASAP (INSEMA) DI KELURAHAN BOJONGKERTA, KEC. BOGOR SELATAN, KOTA BOGOR TAHUN 2019
}

\author{
Andi Asnifatima ${ }^{1}$, Andres Derryl Martin ${ }^{2}$, Satvica Kalbu ${ }^{2}$ \\ andiasnifatimah@gmail.com \\ Dosen Program Studi Kesehatan Masyarakat, Fakultas Ilmu Kesehatan, UIKA Bogor ${ }^{1}$ \\ Mahasiswa PBL Terintegrasi Kelompok 10 Prodi Kesmas, Fikes UIKA Tahun $2019^{2}$
}

\begin{abstract}
ABSTRAK
Sebagian besar sampah rumah tangga tidak terkelola dengan baik sehingga berpotensi mengakibatkan pencemaran lingkungan, media perkembangbiakan dan penularan penyakit. Masalah serupa yang dihadapi oleh warga Kelurahan Bojongkerta, Kec. Bogor Selatan, Kota Bogor, yakni rendahnya tingkat partisipasi warga dalam mengelola sampah rumah tangga sehingga banyak timbulan sampah dan pembakaran sampah terbuka, hal ini bisa memicu terjadinya pencemaran udara dan penyakit yang mengganggu saluran pernapasan sehingga tujuan umum dari kegiatan pengabdian kepada masyarakat ini adalah untuk meningkatkan partisipasi aktif dan peran serta masyarakat dalam mengolah sampah rumah tangga yang dihasilkan sehingga dapat mengurangi dampak buruk sampah rumah tangga baik terhadap kesehatan masyarakat maupun terhadap kesehatan lingkungan. Sedangkan tujuan khusus yang ingin dicapai dalam kegiatan ini adalah untuk memberikan pemahaman yang benar dan alternatif solusi yang sederhana, murah dan mudah diaplikasikan dalam kehidupan seharaihari dalam mengurangi dan mengolah sampah yang dihasilkan dari sisa aktivitas domestik melalui pendekatan dengan metode pemicuan yakni mendorong perubahan perilaku dengan memberikan pengetahuan dan pelatihan berupa workshop pengolahan sampah mandiri agar warga memiliki alternatif dalam mengolah sampah rumah tangga yang sifatnya kering (baik organik dan anorganik) yaitu dengan insenerasi sederhana minim asap (Insema) sehingga bisa mengurangi dampak pencemaran akibat pembakaran sampah. Metode evaluasi dalam kegiatan ini adalah pre dan post test sebelum dan sesudah kegiatan untuk mengukur tingkat pengetahuan, sikap dan perilaku peserta. Hasil yang dicapai menunjukkan peningkatan pengetahuan, sikap dan perilaku peserta dalam mengolah sampah rumah tangga mandiri dengan insenerasi sederhana minim asap (Insema) sebelum dan sesudah workshop. Sehingga dapat disimpulkan bahwa kegiatan ini efektif meningkatkan pengetahuan dan perilaku warga dalam mengolah sampah secara mandiri berbasis rumah tangga. Diharapkan kegiatan ini bisa membentuk pola pikir, pemahaman, sikap dan prilaku hidup bersih dan sehat bagi tokoh masyarakat dan aparat kelurahan/desa yang nantinya akan menjadi role model (panutan) bagi warga disekitarnya.
\end{abstract}

Kata kunci: sampah rumah tangga, pengolahan sampah mandiri, insenrasi sederhana minim asap (insema) 


\section{PENDAHULUAN}

\subsection{Analisis Situasi}

Kelurahan Bojongkerta merupakan salah satu kelurahan yang berada di Kecamatan Bogor Selatan Kota Bogor Provinsi Jawa Barat. Dahulu, Bojongkerta adalah salah satu desa di Kecamatan Ciawi, Kabupaten Bogor, Jawa Barat, Indonesia. Namun, sejak tahun 1995, desa ini secara resmi masuk ke dalam wilayah Kecamatan Bogor Selatan, Kota Bogor. Memiliki Luas wilayah ; 216.785 Ha.

Hasil identifikasi awal pada 135 Kepala Keluarga (KK) sebagai sampel yang diambil dari RW 01 RT 03, 04, dan 05 diperoleh gambaran kondisi kesehatan masyarakat secara umum. Jika berdasarkan indikator perilaku hidup bersih dan sehat seperti cuci tangan data menujukkan sudah baik, sekitar $97 \%$ rumah tangga mengatakan bahwa keluarganya sudah terbiasa mencuci tangan pakai sabun. Kepemilkan jaminan kesehatan warga bojongkerta sudah mencapai 96\%).

Namun masih banyak juga indikator yang membutuhkan intervensi lebih lanjut agar masyarkat bisa paham dengan baik akan pentingnya kesehatan diantaranya berdasarkan indikator persalinan kebanyakan warga masih melahirkan dirumah dengan bantuan tenaga dukun (paraji) sekitar 68\%, sedangkan yang sudah menggunakan fasilitas pelayanan kesehatan masih sedikit (32\%). perilaku warga yang gemar merokok sebanyak 66,6\%. 69,6\% tidak melakukan aktivitas.

Kondisi sanitasi dan ksehatan lingkungan seperti jarak sumber air minum dan septic tank di suatu rumah sekitar 5 meter $(33,3 \%)$ sedangkan batas aman jarak sumber air minum dan septic tank adalah 10 meter. Itu berarti masih banyak rumah yang kuran baik dalam memposisikan jarak sumber air minum dengan septic tanknnya. Berdasarkan kondisi rumah sekitar 54\% rumah terdapat jendela tetapi jarang dibuka. Masih banyak masyarakat yang tidak memberikan imunisasi dasar lengkap kepada anaknya sebanyak (69\%). Warga yang tidak memiliki tempat sampah dirumah 66\%. 71,8\% warga tidak memilah sampahnya dan cara pengolahan sampah dengan cara dibakar pada lahan terbuka $84,4 \%$ dan dibuang ke lahan kosong sebanyak 21 rumah $(15,6 \%)$.

Dengan memperhatikan data diatas bisa disimpulkan bahwa Kelurahan Bojongkerta merupakan desa yang berada dalam wilayah administrasi perkotaan, sangat dekat dengan kemajuan peradaban, pembangunan, pusat pendidikan dan pengetahuan serta teknologi, namun warganya banyak yang mengabaikan pentingnya pemeliharaan kesehatan, kebersihan dan kelestarian lingkungan, kurangnya parsipasi masyarakat dalam upaya kesehatan, seperti pengolahan sampah rumah tangga, perilaku bersih dan sehat, sanitasi, dll. Disinilah peran komunitas perguruan tinggi, akademisi dan ilmuwan untuk membantu menyelesaikan masalah - masalah yang dihadapi masyarakat dan turut serta menyukseskan program GERMAS (Gerakan Masyarakat Sehat). Oleh karen itu kami terpanggil untuk melakukan kegiatan pengabdian masyarakat demi menjalankan peran pengabdian masayarakat komunitas perguruan tinggi dibidang kesehatan masyarakat.

\subsection{Permasalahan yang Dihadapi}

Berat timbunan sampah di Indonesia secara nasional mencapai 200 ribu ton per hari atau setara dengan 73 juta ton per tahun dan paling dominan berasal dari 
sampah rumah tangga. Riset terbaru Sustainable Waste Indonesia (SWI) mengungkapkan sebanyak $24 \%$ sampah di Indonesia masih tidak terkelola termasuk sampah rumah tangga. Hal serupa yang dihadapi oleh warga Kelurahan Bojongkerta, Kec. Bogor Selatan, Kota Bogor, yakni rendahnya tingkat partisipasi warga dalam mengelola sampah rumah tangga yang dihasilkan sehingga banyaknya timbulan sampah yang tersebar hampir diseluruh RT dan sebagian besar warga tidak memiliki tempat sampah khusus apalagi melakukan pemilahan sampah.

Berdasarkan analisis situasi diatas yang paling menonjol dan memungkinkan berdampak luas terhadap kesehatan masayarakat adalah kondisi sanitasi dan kesehatan lingkungan, yakni masalah sampah rumah tangga. Di Kelurahan Bojongkerta, khususnya di RW 01 RT 03, 04 dan 05 tidak ada tempat pembuangan sampah sementara (TPS) yang memungkinkan bagi Dinas Kebersihan Kota Bogor untuk lokalisasi pengumpulan sampah sementara sebelum diangkut ke TPA (tempat pembuangan akhir) sebab pemerintah setempat tidak memfasilitasi juga tidak ada inisiatif swadaya masyarakat untuk menyumbangkan lahan mereka untuk dijadikan TPS. Akibatnya warga setempat tidak memiliki pilihan pembuangan sampah selain membakar dan menumpuk sampahnya di lahan terbuka atau dikebun-kebun disekitar rumah mereka, tentunya hal ini sangat berisiko terjadinya pencemaran udara akibat membakar sampah, hal ini turut berkontribusi terhadapa banyaknya kejadian ISPA dan Pneumonia baik lansia, dewasa mauoun balita. Selain itu sampah juga merusak estetika lingkungan, tidak enak dilihat dan membuat ketidaknyamanan serta yang paling dikhawatirkan adalah makin mudahnya penyebaran penyakit akibat lingkungan seperti diare, TB, DBD, Malaria, Tipes, Hepatitis, dll karena sampah bisa menjadi media perkembanganbiakan agen penyakit seperti tikus, lalat dan nyamuk.

\subsection{Solusi yang Ditawarkan}

Masalah utama yang dihadapi adalah kurangnya partisipasi aktif masayarakat dalam mengolah sampah rumah tangga masing-masing, hal ini bisa disebabkan oleh beberapa hal diantaranya warga tidak cukup pengetahuan dan pemahaman terkait jenis sampah dan cara mengolahnya, kurangnya dorongan dan pendampingan aparat setempat dalam hal pengolahan sampah serta warga tidak memiliki alternatif pengolahan sampah selain membakar dan menimbun. Dengan demikian solusi yang ditawarkan adalah melakukan Workshop Pengolahan Sampah Mandiri dengan Insenerasi Sederhana Minim Asap. Hal ini merupakan salah satu cara yang tepat untuk memberikan pengetahuan dan pemahaman yang benar dan alternatif solusi yang sederhana, murah dan mudah diaplikasikan dalam kehidupan seharaihari dalam mengurangi dan mengolah sampah yang dihasilkan dari sisa aktivitas domestik dengan melibatkan aparat kelurahan mulai dari tingkat RT, RW, perwakilan kelurahan, ibu-ibu kader dan puskesmas sebagai peserta karena mereka inilah yang nantinya akan menjadi penggerak bagi warga disekitarnya. Sehingga ketiga masalah tersebut diatas sekaligus bisa teratasi.

Workshop merupakan proses kegiatan belajar secara berkelompok ataupun individual tentang suatu masalah kemudian merumuskan solusi dan belajar mempraktikkannya sehingga melalui 
kegiatan workshop dengan metode pemicuan ini peserta yang hadir diharapakn bisa memahami dengan baik kemudian menerapkan sendiri dalam kehidupan sehari-hari yang nantinya akan menjadi role model (panutan/contoh) yang membuat warga lainnya akan tergerak melakukan hal sama.

Insenerasi sederhana minim asap (Insema) merupakan alat pembakar sampah yang sifatnya kering (baik sampah organik seperti kertas, daun dan ranting maupun sampah anorganik seperti plastik kemasan, kardus, gabus, botol kemasan, dll) yang dirancang secara sederhana dari Drum/Tong bekas wadah BBM (Bahan Bakar Minyak) yang diinstalasi dengan cara pengelasan dan dilengkapi cerobong asap sepanjang 2 meter dengan filter sabut kelapa yang basah untuk memfilter sisa pembakaran.

Cara kerja alat ini adalah dengan memusnahkan sampah padat yang kering melalui pembakaran dan asap yang dihasilkan telah melalui proses filtrasi sabut kelapa basah untuk menurunkan tingkat polusi yang dihasilkan oleh asap sisa pembakaran tersebut.

Cara pakai Insema :

1. Kumpulkan sampah mudah terbakar seperti daun kering, ranting dan kertas, plastik dan botol kemasan, gabus dsb. Lalu masukan ke dalam tong pembakaran melalui pintu masuk sampah lalu tutup rapat.

2. Siapkan pembakaran, kayu/ranting dapat menjadi sumbu pembakaran untuk mempercepat bisa memakai minyak tanah.

3. Masukkan serabut kelapa basah ke lubang asap.
4. Tutup rapat semua pintu, kecuali pintu pembakaran dibuka sedikit agar oksigen masuk dan apinya tidak padam.

5. Jika sampah sudah habis terbakar, abu dapat dikeluarkan melalui pintu bagian bawah.

Kelebihan :

1. Mengurangi polusi udara dan mencegah terpaparnya masyarakat dari zat-zat berbahaya yang dihasilkan oleh pembakaran sampah terbuka.

2. Memusnahkan sampah rumah tangga terutama sampah kering seperti ranting kayu, daun, kertas, kardus, plasstik dan botl kemasan, dll.

3. Mudah dipakai dan dipindahkan

Kelemahan :

1. Api mudah mati karena kurangnya oksigen yang dapat masuk, masih butuh modifikasi lubang udara

2. Mengganti serabut kelapa untuk filter asap

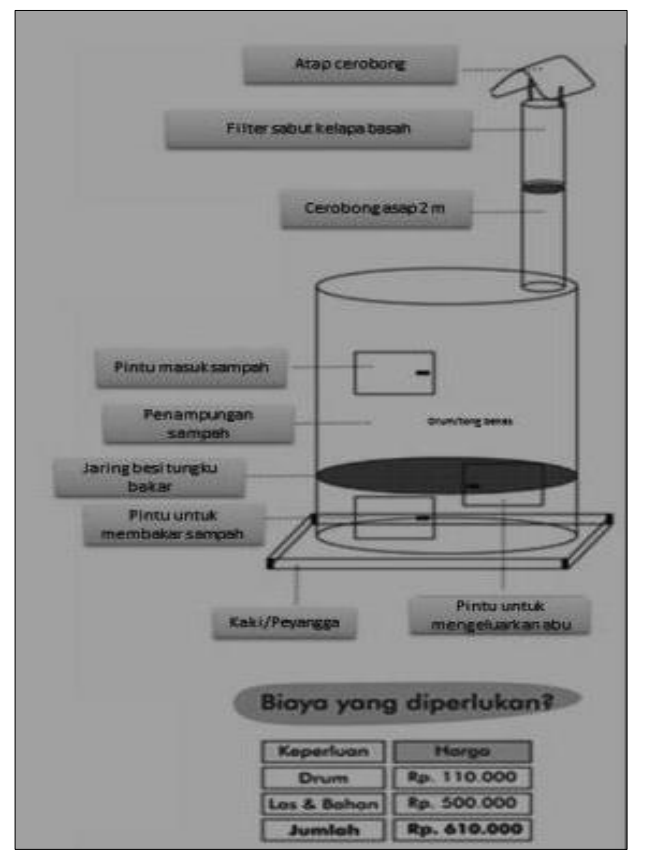

Gambar 1. Desain Insema 


\section{DESKRIPSI LOKASI KEGIATAN}

\subsection{Keadaan Geografis}

Asal mula berdirinya Kelurahan Bojongkerta Kecamatan Bogor Selatan Kota Bogor, Kelurahan Bojongkerta pada awalnya adalah bagian dari Desa Rancamaya yang waktu itu masih masuk wilayah Kabupaten Bogor. Seiring pesatnya perkembangan penduduk sehingga pada tahun 1984 dengan berbagai kajian yang dilaksanakan sebelumnya dan hasil kajian pada saat itu adalah pemekaran desa, maka wilayah Desa Rancamaya dipecah menjadi 3 (tiga) desa yaitu : Desa Rancamaya (sebagai induk desa), Desa Bojongkerja dan Desa Kertamaya.

Pada Bulan Agustus 1995 berdasarkan kajian dari pemekaran Kota Madya Bogor, Desa Bojongkerta berubah status wilayahnya dari Kabupaten Bogor menjadi Kota Madya Bogor dengan perangkatnya yang pada saat itu masih berstatus honor daerah. Pada Bulan September 2000, Perangkat Desa Bojongkerta diangkat menjadi Tenaga Kerja Kontrak Pemerintah Kota Bogor, sejak saat itu juga status Desa Bojongkerta berubah menjadi Kelurahan Bojongkerta.

Secara administratif Kelurahan Bojongkerta terletak di Kecamatan Bogor Selatan Kota Bogor yang memiliki 6 (enam) RW dan 28 (dua puluh delapan) RT, dengan luas wilayah sekitar 216.785 Ha. Kelurahan Bojongkerta berbatasan dengan wilayah Sebelah Utara: Kelurahan Kertamaya; Sebelah Timur: Kelurahan Harjasari; Sebelah Selatan: Jalan Kabupaten/Kota/Desa Bitungsari; Sebelah Barat: Kelurahan Rancamaya;

Adapun secara topografi bentang lahan daratan di Kelurahan Bojongkerta sebagian besar pergunakan untuk pemukiman penduduk dan perkebunan. Kondisi tanah secara umum bertebing dan curam sehingga mudah terjadi longsor pada waktu musim hujan yang berkepanjangan.

\subsection{Kondisi Demografis}

Jumlah Penduduk Kelurahan Bojongkerta tercatat sebanyak 8.784 jiwa yang tersebar dalam 6 RW dan 29 RT dengan rincian sebagai berikut:

Tabel 1. Jumlah penduduk Kel. Bojongkerta

\begin{tabular}{|c|c|}
\hline Jumlah laki-laki & 4532 Orang \\
\hline Jumlah Perempuan & 4252 Orang \\
\hline Jumlah Total & 8784Orang \\
\hline $\begin{array}{c}\text { Jumlah Kepala } \\
\text { Keluarga }\end{array}$ & $2711 \mathrm{KK}$ \\
\hline $\begin{array}{c}\text { Kepadatan } \\
\text { Penduduk }\end{array}$ & 100 Per km \\
\hline
\end{tabular}

Sumber : Profil Kel. Bojongkerta, 2018

Tabel 2. Jumlah Penduduk Kel Bojongkerta berdasarkan RW

\begin{tabular}{|c|c|c|c|}
\hline \multirow{2}{*}{ RW } & \multicolumn{3}{|c|}{ Jumlah } \\
\cline { 2 - 4 } & $\begin{array}{c}\text { Laki- } \\
\text { laki }\end{array}$ & $\begin{array}{c}\text { Perempu } \\
\text { an }\end{array}$ & Jumlah \\
\hline 01 & 842 & 852 & 1694 \\
\hline 02 & 1.360 & 1.289 & 2.649 \\
\hline 03 & 732 & 664 & 1396 \\
\hline 04 & 467 & 444 & 911 \\
\hline 05 & 548 & 500 & 1.048 \\
\hline 06 & 583 & 503 & 1.086 \\
\hline Total & $\mathbf{4 . 5 3 2}$ & $\mathbf{4 . 2 5 2}$ & $\mathbf{8 . 7 8 4}$ \\
\hline
\end{tabular}

Sumber : Profil Kel. Bojongkerta, 2018

Tabel 3. Jumlah Penduduk menurut tingkat pendidikan

\begin{tabular}{|c|c|c|}
\hline \multirow{2}{*}{$\begin{array}{c}\text { Tingkat } \\
\text { Pendidikan }\end{array}$} & \multicolumn{2}{|c|}{ Jumlah } \\
\cline { 2 - 3 } & Laki-laki & $\begin{array}{c}\text { Perem } \\
\text { puan }\end{array}$ \\
\hline $\begin{array}{c}\text { Usia 18-56 } \\
\text { tahun pernah }\end{array}$ & - & 31 \\
Orang \\
\hline
\end{tabular}




\begin{tabular}{|c|c|c|}
\hline $\begin{array}{c}\text { SD tidak tamat } \\
\text { Tamat }\end{array}$ & $\begin{array}{c}255 \\
\text { Orang }\end{array}$ & $\begin{array}{c}189 \\
\text { Orang }\end{array}$ \\
\hline $\begin{array}{c}\text { Usia 12-56 } \\
\text { tahun tidak } \\
\text { tamat SLTP }\end{array}$ & $\begin{array}{c}215 \\
\text { Orang }\end{array}$ & $\begin{array}{c}155 \\
\text { Orang }\end{array}$ \\
\hline $\begin{array}{c}\text { Usia 18-56 } \\
\text { tahun tidak } \\
\text { tamat SLTA }\end{array}$ & 85 Orang & $\begin{array}{c}45 \\
\text { Orang }\end{array}$ \\
\hline $\begin{array}{c}\text { Tamat D- } \\
\text { 3/Sederajat }\end{array}$ & 10 Orang & $\begin{array}{c}5 \\
\text { Orang }\end{array}$ \\
\hline $\begin{array}{c}\text { Tamat S- } \\
\text { 1/Sederajat }\end{array}$ & 10 Orang & $\begin{array}{c}7 \\
\text { Orang }\end{array}$ \\
\hline $\begin{array}{c}\text { Tamat S- } \\
\text { 2/Sederajat }\end{array}$ & - & $\begin{array}{c}1 \\
\text { Orang }\end{array}$ \\
\hline Jumlah & $\mathbf{1 . 0 4 4}$ Orang \\
\hline
\end{tabular}

Sumber : Profil Kel. Bojongkerta, 2018

\subsection{Ketersediaan Fasilitas Umum Dan Sanitasi}

Sarana transportasi berupa jalan desa yang beraspal dalam kondisi baik sepanjang $6 \mathrm{~km}$ atau unit, jalan tanah belum diaspal sepanjang $2 \mathrm{~km}$ atau unit, jalan konblok $2 \mathrm{~km}$ atau unit. Prasarana angkutan darat berupa pangkalan ojek ada 6 unit.

Sarana air bersih dan sanitasi berupa sumur pompa ada 3 unit, sumur gali ada 7 unit, hidran umum ada 12 unit, tangki air bersih ada 2 unit dan ada sumber mata air. Terdapat fasilitas sanitasi berupa drainase/saluran pembuangan air limbah, jumlah MCK Umum 18 unit, dan pemilik jamban keluaraga 255 KK. Sedangkan sarana dan prasarana kebersihan berupa TPS, TPA, Alat penghancur sampah, tong, truk, gerobak, satgas dan tempat pengelolaan sampah tidak ada.

Sarana Pendidikan yang ada di kelurahan Bojongkerta adalah 1 TK, 1 SD, 2 SMP, tidak ada SMA, tidak asa SMK, 2 MI, 5 PAUD, 14 Pondok Pesantren. Sarana peribadatan gterdiri dari 12 Masjid, 28 Mushola, dan 1 gereja katolik. Fasilitas Kesehatan terdiri dari 1 Puskesmas Pembantu dan 14 Posyandu. Fasilitas Olahraga terdiri 2 lapangan Sepak Bola dan 1 Lapangan Bulu tangkis. 


\section{METODE PELAKSANAAN}

\section{Tahapan Pelaksanaa}

Tahapan pelaksanaan untuk kegiatan ini sebagaimana terlihat pada bagan sebagai berikut :

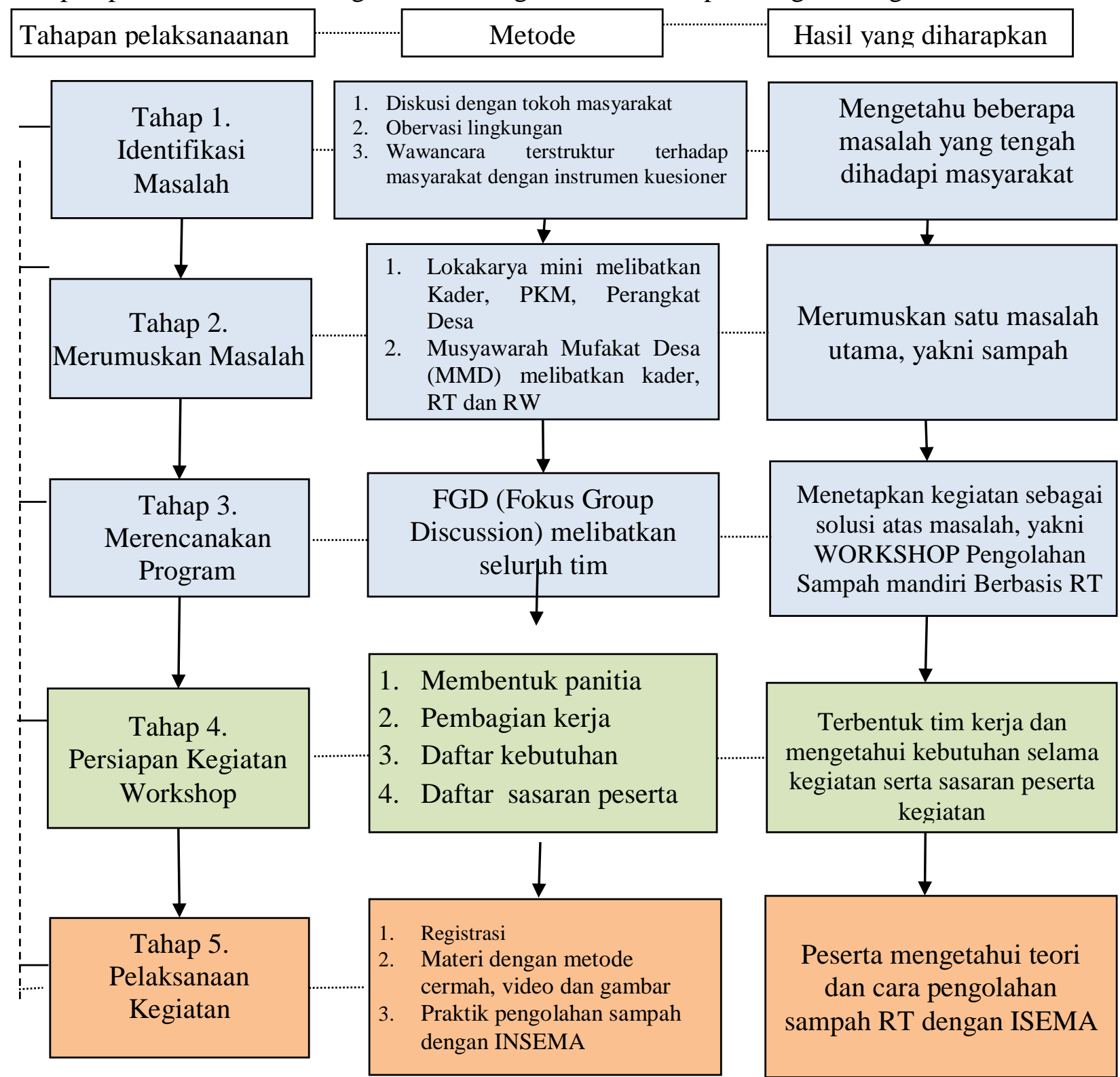

Bagan 1. Bagan Alir Pelaksanaan

Tabel 4. Jadwal Kegiatan

\begin{tabular}{|c|l|l|l|l|l|}
\hline No. & \multicolumn{1}{|c|}{ Kegiatan } & \multicolumn{4}{c|}{ Mingu } \\
\hline & & I & II & II & IV \\
\hline 1 & Identifikasi Masalah & & & & \\
\hline 2 & Merumuskan Masalah & & & & \\
\hline 3 & Merencanakan Program & & & & \\
\hline 4 & Persiapan Kegiatan Workshop & & & & \\
\hline 5 & Pelaksanaan Kegiatan & & & & \\
\hline
\end{tabular}




\subsection{Metode Pendekatan}

Metode yang digunakan dalam kegiatan ini adalah metode pemicuan, yakni cara untuk mendorong perubahan perilaku higienis dan saniter individual atau masyarakat atas kesadaran sendiri dengan menyentuh perasaan, pola pikir, perilaku dan kebiasaan individu atau masyarakat guna meningkatkan partisipasi aktif warga setempat dalam mengolah sampah rumah tangga secara madiri.

Metode ini sering diaplikasikan dalam program STBM ( Sanitasi Total Berbasis Masyarakat) dengan pendekatan terhadap masyarakat dengan memberikan contoh tentang pola hidup sehat dan bagaimana sebaran penyakit yang sering di terjangkit di masyarakat akibat sampah yang tidak dikelola. Sasaran utama kegiatan ini adalah para tokoh masyarakat dan aparat kelurahan/desa setempat karena mereka inilah yang akan menjadi motor penggerak warga disekitar mereka mulai dari kepala desa, aparat dan perangkat desa RT dan RW, ibu kader posyandu/puskesmas. Metode ini diperlukan guna mendorong percepatan kegiatan pengelolaan sampah rumah tangga yang bermanfaat bagi seluruh lapisan masyarakat. Pengolahan sampah rumah tangga ini harus benar - benar dijalankan oleh setiap warga desa sebab manfaatnya Dari, Oleh dan Untuk Masyarakat itu sendiri.

\subsection{Partisipasi Masyarakat dalam Pelaksanaan Program}

Partisipasi masyarakat yang dilakukan dalam kegiatan ini adalah sebagai berikut:
1. Melibatkan pihak aparat kelurahan setempat sebagai peserta juga sebagai penggerak tokoh masyarakat, hal ini sangat penting akrena aparat kelurahan merupakan kunci utama kesuksesan kegiatan ini dan keberlangsungan kegiatan pengolahan sampah mandiri berbasis rumah tangga dimasa yang akan datang.

2. Melibatkan tokoh masyarakat seperti ketua RW, RT dan kader posyandu yang aktif sebagai peserta utama dengan tujuan setelah kegiatan ini nantinya mereka yang akan menjadi role model bagi warga masayarakat setempat agar mengolah sampah dengan bijak.

3. Lokasi atau tempat kegiatan ini berlangsung difasilitasi oleh warga setempat, yakni di Posyandu.

4. Peralatan berupa LCD untuk penyampaian materi difasilitasi oleh pihak Kelurahan Bojongkerta

\subsection{Langkah Evaluasi}

Metode evaluasi dilakukan dengan cara pre dan post test, yakni wawancara melalui kuesioner untuk mengukur tingkat pengetahuan, sikap dan perilaku peserta sebelum dan setelah kegiatan ini berlangsung. Setiap peserta yang melakukan registrasi akan diberikan kuesioner untuk diisi sebelum materi dimulai. Dan setelah seluruh rangkaian kegiatan telah terlaksana peserta diberikan lagi kuesioner untuk diisi dengan bantuan dari tim. 


\section{HASIL DAN PEMBAHASAN}

\subsection{Pelaksanaan Program}

Kegiatan workshop pengolahan sampah mandiri berbasis rumah tangga dilaksanakan pada tanggal 31 Oktober 2019 yang berlangsung di Posyandu RT 04 (Posyandu Nila), RW 01, Kelurahan Bojongkerta, Kec. Bogor Selatan, Kota Bogor dengan jumlah peserta 17 orang yang terdiri diri dari aparat desa RT dan RW, perwakilan dari Kelurahan, ibu kader posyandu dan petugas puskesmas (daftar hadir terlampir) yang di mulai dari jam 08.00 (pagi) - jam 12 (siang) dengan 2 sesi masing. Sesi pertama penyampaian materi dan sesi kedua praktik membuat Lukonik dan dan tutorial menggunakan Dirangga.

Kegiatan ini diawali dengan registrasi peserta dan pengisian kuesioner pre test oleh semua peserta yang dipandu oleh tim panitia kemudian acara dilanjutkan dengan pembukaan secara resmi oleh perwakilan Kepala Kelurahan Bojongkerta, setelah itu dilanjutkan sesi materi dengan metode ceramah dalam memaparkan materi.

Materi pada sesi I adalah pengantar tentang sampah meliputi pengertian sampah berserta jenis-jenisnya beserta dampak kesehatan lingkungannya, pengenalan sampah organik dan anorganik, alternatif pengolahan sampah dengan instalasi alat insenerasi sederhana minim asap dengan filter sabuk kelapa basah (Insema) kemudian peserta diberi kesempatan untuk sharing/diskusi.

Pada sesi II adalah praktik membakar sampah kering yang mudah terbakar seperti daun kering, ranting kertas kardus dan palstik dengan Insema.

Media yang digunakan dalam workshop ini adalah LCD, materi dalam bentuk PPt, Video dan Gambar, contoh prototipe alat.

Para peserta kegiatan ini sangat antusias mengikuti materi, aktif bertanya dan suasana forum menjadi menarik dengan pertanyaan sederhana tapi penting. Kegiatan berlangsung kurang lebih selama 4 jam, dan penutupan dilaksanakan pada pukul 12.00 yang dilanjutkan dengan foto bersama dan penyerangan kenangkenangan berupa plakat dan protipe Dirangga kepada warga secara simbolik yang diwakili perakilan kelurahn dan ibu kader yang merupakan tanda peserta siap menjadi agen of change dilingkungan tempat tinggal masing-masing.
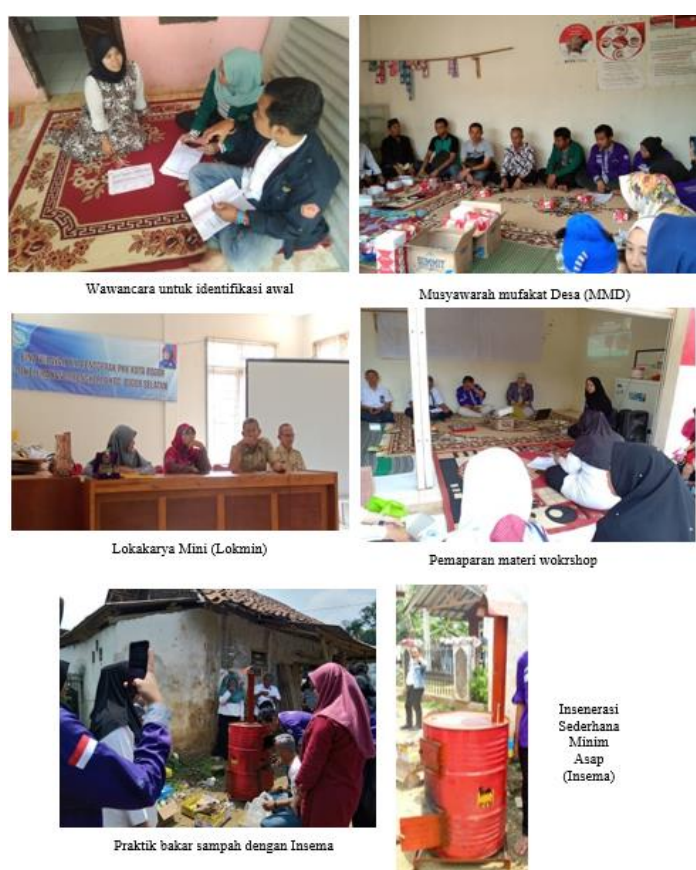

\subsection{Capaian Program}

Pengukuran keberhasilan kegiatan ini dilakukan melalui pre dan post test sebelum dan sesudah kegiatan dilaksanakan, tujuannya untuk mengetahui tingkat pengetahuan, sikap dan perilaku warga masyarakat yang terwakili oleh peserta kegiatan yang berjumlah 17 orang berasal dari berbagai latar belakang 
jabatan, ada aparat desa RT, RW, ibu-ibu kader posyandu dan puskesmas.

1. Pengetahuan

Berdasarkan hasil pre dan psot test variabel pengetahuan diperoleh hasil sebagai berikut :

Tabel 6. Tingkat Pengetahuan tentang pengolahan sampah rumah tangga

\begin{tabular}{|l|l|l|l|l|}
\hline \multirow{2}{*}{ Pengetahuan } & \multicolumn{2}{l|}{ Pre Test } & \multicolumn{2}{l|}{ Post Test } \\
\cline { 2 - 5 } & n & \% & n & \% \\
\hline Tinggi & 6 & 35 & 16 & 94 \\
\hline Sedang & 5 & 29 & 1 & 6 \\
\hline Kurang & 6 & 35 & 0 & 0 \\
\hline Total & 17 & 100 & 17 & 100 \\
\hline
\end{tabular}

Berdasarkan tabel 6 menunjukkan

bahwa pengetahuan peserta sebelum kegiatan workshop dilakukan diperoleh $35 \%$ peserta memiliki pengetahuan yang tinggi, $29 \%$ memiliki pengetahuan yang sedang dan $35 \%$ memiliki pengetahuan yang kurang, namun setelah kegiatan workshop pengetahuan yakni $94 \%$ peserta tingkat pengetahuannnya tergolong tinggi dan $6 \%$ pengetahuannya sedang dan tidak ada lagi yang memiliki pengetahuan kurang $(0 \%)$.

2. Sikap

Berdasarkan hasil pre dan psot test variabel sikap diperoleh hasil sebagai berikut :

Tabel 7. Sikap tentang pengolahan sampah rumah tangga

\begin{tabular}{|l|l|l|l|l|}
\hline \multirow{2}{*}{ Sikap } & \multicolumn{2}{|l|}{ Pre Test } & \multicolumn{2}{l|}{ Post Test } \\
\cline { 2 - 5 } & $\mathbf{n}$ & $\boldsymbol{\%}$ & $\mathbf{n}$ & $\boldsymbol{\%}$ \\
\hline Positif & 9 & 47 & 17 & 100 \\
\hline Negatif & 8 & 53 & 0 & 0 \\
\hline Total & 17 & 100 & 17 & 100 \\
\hline
\end{tabular}

Berdasarkan tabel 7 menunjukkan bahwa sebelum kegiatan workshop dilakukan sikap peserta terhadap pengolahan sampah rumah tangga yang dihasilkan $47 \%$ bersikap positif dan 53 $\%$ bersikap negatif sedangkan setelah kegiatan workshop dilakukan diperoleh $100 \%$ peserta bersikap positif terhadap upaya pengolahan sampah rumah tangga.

3. Perilaku

Berdasarkan hasil pre dan psot test variabel sikap diperoleh hasil sebagai berikut :

Tabel 8. Perilaku terhadap pengolahan sampah

\begin{tabular}{|l|l|l|l|l|}
\hline \multirow{2}{*}{ Perilaku } & \multicolumn{2}{c|}{ Pre Test } & \multicolumn{2}{l|}{ Post Test } \\
\cline { 2 - 6 } & n & $\%$ & n & $\%$ \\
\hline Baik & 14 & 82 & 16 & 94 \\
\hline Buruk & 3 & 18 & 1 & 6 \\
\hline Total & 17 & 100 & 17 & 100 \\
\hline
\end{tabular}

menunjukkan bahwa sebelum kegiatan dilakukan diperoleh $82 \%$ peserta yang berperilaku baik terhadap pengolahan sampah rumah tangganya dan selebihnya $18 \%$ berperilaku buruk, namun setelah kegiatan workshop dilaksanakan terjadi peningkatan perilaku baik $(94 \%)$ dan yang berprilaku buruk hanya $6 \%$.

\subsection{Dampak Bagi Masyarakat}

Kegiatan workshop pengolahan sampah mandiri dengan insenerasi sederhana minim asap (Insema) memberikan dampak positif bagi masayarakat kearah yang lebih baik terhadap pengetahuan, sikap dan perilaku masyarakat dalam mengolah sampahnya. Dari hasil pre dan post test diketahui tejadi peningkatan pengetahuan, sikap daan perilaku peserta. Dengan dukungan pemerintah setempat dalam hal ini aparat kelurahan akan sangat memungkinkan warga desa mengolah secara mandiri sampah yang dihasilkan dari rumah 
masing-masing sehingga lambat laun masalah sampah ini bisa diselesaikan dari hulu kehilirnya, tentu dengan partisipasi aktif masyarakatnya bukan hal yang tidak

\section{PENUTUP}

\subsection{Kesimpulan}

Kegiatan workshop pengolahan sampah mandiri dengan insenerasi sederhana minim asap (Insema) secara efektif meningkatkan pengetahuan, sikap dan perilaku warga Kelurahan Bojongkerta terhadap pengolahan sampah rumah tangga.

\subsection{Rekomendasi}

Disarankan kepada pemerintah setempat agar segera menugaskan aparat mungkin warga Kelurahan Bojongkerta bisa mandiri mengelola sampah rumah tangga masing-masing.

kelurahan yang telah mengikuti workshop untuk aktif melakukan pendampingan dan pelatihan kepada warga serta memfasilitasi warganya yang ingin membuat alat Insema serta mendorong swadaya masyarakat untuk membuat TPS dan Tempat Pengolahan Sampah Mandiri yang dikelola secara swadaya dan menghasilkan omset minimal per RT. Kepada pihak Puskesmas terutama bagian Kesehatan lingkungan aktif melakukan penyuluhan dan monitoring sampah warga. 


\section{REFERENSI}

Garini, A. (2012). Pengetahuan, Sikap dan Perilaku Siswa Sekolah Dasar Negeri Terhadap Pengolahan Sampah Di Kecamatan Bantar Gebang Kota Bekasi Tahun 2012. Skripsi. Depok. FKM UI.

Hayat, Hasan Zayadi. (2018). Model Inovasi Pengelolaan Sampah Rumah Tangga. Jurna Ketahanan Pangan JU-Ke, Volume 2, Nomor 2, Desember 2018, hlm. 131 - 141.

Ika Wahyuning Widiarti. (2012). Pengelolaan Sampah Berbasis "Zero Waste" Skala Rumah Tangga Secara Mandiri. Jurnal Sains dan Teknologi Lingkungan Volume 4, Nomor 2, Juni 2012, Halaman 101113. ISSN: 2085-1227.

Kamal, F. (2009). Hubungan Antara Tingkat Pengetahuan Dan Sikap Ibu Rumah Tangga Tentang Pengelolaan Sampah Dengan
Perilaku Pembuangan Sampah Pada Masyarakat Sekitar Sungai Beringin Di Rw 07 Kelurahan Wonosari Kecamatan Ngaliyan Kota Semarang Tahun 2009. Skripsi. Semarang. FIK Universitas Negeri Semarang.

Martinawati. (2016). Partisipasi Masyarakat dalam Pengelolaan Sampah Rumah Tangga: Sebuah Studi di Kecamatan Sukarami Kota Palembang. Jurnal Penelitian Sains Volume 18 Nomor 1 Januari 2016. Riau. JPS MIPA UNSRI.

Wijayanti, RA, dkk. (2016). Efektifitas Penyuluhan Perilaku Hidup Bersih DanSehat (Phbs) Dalam Meningkatkan Pengetahuan Siswa Di Smp Islam Mahfilud Duror Jelbuk. Jurnal Ilmiah INOVASI, Vol. 1 No. 3 Edisi SeptemberDesember 2016, ISSN 1411-5549. 